\title{
REVIEW OF NORMATIVE DOCUMENTS APPLICABLE IN POLISH NAVY IN THE FIELD OF MEASUREMENT AND MINIMALIZATION OF SHIPS PHYSICAL FIELDS
}

\author{
Piotr Kubis*1(D), Małgorzata Gloza*2(D), Rafał Józwiak*3 (i), \\ Katarzyna Kamińska**(D)
}

* Polish Naval Academy, Faculty of Navigation and Naval Weapons, Śmidowicza 69 Str., 81-127 Gdynia, Poland; e-mail: p.kubis@amw.gdynia.pl,m.gloza@amw.gdynia.pl,r.jozwiak@amw.gdynia.pl; ORCID ID: 10000-0002-9321-7481, 20000-0002-8330-0185, 30000-0001-7513-6672

** Polish Navy Control and Measurement Unit, War Port Command, Rondo Bitwy pod Oliwa 1 Str., 81-103 Gdynia, Poland; e-mail: k.kaminska1310@gmail.com; ORCID ID 0000-0002-6185-518X

\begin{abstract}
The article presents the general organization and operating principles of the national departmental standardization system. The characteristics of the tasks carried out in the area of defense and security, in the new formal, legal, and organizational conditions related to the passive defense of the Polish Navy ships are presented. In addition, the article contains a brief description of standardization documents in the area of national defense applied in the Armed Forces of Poland. One of the areas related to the passive defense and measurements of physical fields in the Polish Navy was also indicated.

Normalization is a way by which the Polish Navy can support the development of the military potential through the introduction of new equipment and weapons, which also contributes to the development of scientific research.
\end{abstract}

\section{Keywords:}

defense standards, normalization, normative documents, measurements of the ship's physical fields, passive defense of the ship.

Research article

(C) 2019 Piotr Kubis, Małgorzata Gloza, Rafał Józwiak, Katarzyna Kamińska This is an open access article licensed under the Creative Commons Attribution-NonCommercial-NoDerivatives 4.0 license (http://creativecommons.org/licenses/by-nc-nd/4.0/) 


\section{INTRODUCTION}

The standardization tasks are preformed to ensuring the proper quality of specialist military equipment purchased for defense purposes in the Polish Armed Forces. The normalization in this area include terms of organization and documentation. In this issue, at the national level, there is the problem of the final ordering of rules related to the existing collections of Industry Standards, Military Industry Standards, Military Polish Standards, special attachments created for the time of threat and war, and many other types of standardization documents. This is a big challenge not only for the Ministry of National Defense. The success of this undertaking will depend on the involvement of other departments, especially the department of investment and economic development and department of internal affairs and communication. There is also an urgent need to include the defense industry in standardization activities, especially in the aspect of design and production of armaments and military equipment, including ratification of agreements and NATO standardization recommendations in this area. Many various issues in terms of the defense system, differently qualified in the priority hierarchy depending on the assessment point and the evaluator. However, it is certain that without an efficiently functioning scientific background, research and development potential, qualified scientific and technical staff, it will be difficult to meet the above-mentioned issues. The improvement process based on scientific and research projects should be accepted as a principle and applied consistently and permanently, regardless of the process of introducing organizational changes, full-time and budget savings. The authors of the study hope that this article will bring the readers closer to issues related to passive defense normalization and its importance in orders for military technology in current and future organizational conditions, at the national and departmental levels.

Standardization is an activity aimed at obtaining an optimal degree of order in a specific field, by setting provisions intended for common and repeated use, regarding existing or possible technical problems. Important benefits of standardization are improving the suitability of products, processes, and services for the purposes for which they are to be used, preventing barriers, and facilitating technical cooperation [7]. For this reason, the Polish Armed Forces are working in many areas to improve technical development and eliminate the phenomenon of duplication of scientific research.

This activity consists in particular in developing, publishing, and applying standards. Standards should be based on the achievements of both science, technology, and practice, and should aim to achieve optimal social benefits. 
This paper will present normative documents in the Polish Navy regarding measurements and minimization of physical fields.

The physical fields generated by the ship have been used for many years in ship detection, location, and identification systems as well as in the systems of selfguidance and the initiation of marine armament systems [1]. At the same time, there are ongoing works focused on the development of methods and systems to counteract these types of weapons. Increasingly effective methods of masking, simulation systems of the ship's physical fields and methods of their minimization are being developed. The essence of the passive defense of ships is the skillful use of various compensating and masking means to obtain a relatively low and stable level of physical fields. The parameters of these fields are one of the most guarded secrets in any navy in the world. The Polish Navy also pays special attention to these issues, the effect of which in recent years has been the development and introduction of several standardization documents regarding the issues of measurements and minimization of physical fields of ships.

\section{THE IMPORTANCE OF STANDARDIZATION IN THE POLISH ARMED FORCES ON THE EXAMPLE OF SELECTED STANDARDS USED IN THE POLISH NAVY}

The process of military equipment operation in the Polish Armed Forces, as well as in the Polish Navy, is a very complex area.

To ensure its efficient performance, the system has been divided into appropriate levels. These levels closely depend on each other and complement each other. The military technique operation system can perform efficiently and effectively due to its division into operational management and executive bodies. The management and executive bodies occur at all levels of the operation system. At each organizational level, their commanders are responsible for military equipment's operation and technical condition. The central level executive bodies in the military equipment operation area are military repair and production companies, military research units, military metrology institutions, military-technical supervision, and national economy plants.

The operational level executive bodies in the military equipment operation area: regional technical workshops (OWT), district material bases (RBM), material and technical bases (BMT), district technical workshops (RWT), mobile technical workshops (RuWT), Central Armaments and Aviation Electronics Workshops (CWUiEL), 
Central Navy Depot (CS MW), Central Navy Rescue Equipment Plant (CZSRat MW), field aviation workshop (PWL), repair battalions, repair companies and others.

Citing the provisions of Decision No. 72/MON of March 25, 2013 regarding the acquisition of military equipment and services for the Armed Forces of the Republic of Poland (Official Journal of the Ministry of National Defense of March 25, 2013, item 78, as amended) it can be seen that the organization responsible for the military equipment operation in the Polish Armed Forces is the Armed Forces Support Inspectorate (IWsp SZ).

The head of IWsp SZ in the process of acquiring military equipment and/or services, including operation, implements, inter alia, the following tasks:

- manages the operational phase and is responsible for it;

- implements, through subordinate organizational units, the decentralized deliveries of military equipment, including modified military equipment and military equipment repair services, provided for in the 'Plan for technical modernization of the Armed Forces of the Republic of Poland';

- draws up and issues documents that regulate the principles of military equipment operation and management in the Armed Forces;

- supervises military equipment operation in the Armed Forces and analyzes it.

A large part of this decision was devoted to the importance of standardization documents, especially standards and/or the need to use them. It should be noted that the application of standards is recommended at every stage of the military equipment life cycle, especially at the stage of conceptual and design works, through the phase of research, implementation, operation up to decommissioning in the army and disposal.

Compliance with their provisions is one of the conditions guaranteeing subsequent trouble-free operation. Therefore, for example, the technical requirements (WT) for a piece of given military equipment already recommend relying on defense standard NO-06-A101: 2005 Armaments and military equipment - General technical requirements, methods of control and testing - General provisions. In the initial tactical and technical assumptions (WZTT) - a document developed in the analytical and conceptual phase, it is necessary to ensure first of all that its information structure is consistent with the tactical and technical assumptions (ZTT). Any ZTT draft should be developed in accordance with the relevant defense standard, with particular reference to the critical parameters of the acquired military equipment.

It is clearly emphasized that at the stage of preliminary testing of a prototype (and even a factory model), the product shall be subjected to preliminary/factory (BW) and qualification (BK) tests in accordance with the procedures contained in the relevant standards. 
Upon BW completion, the contractor declares readiness to start the prototype's BK, as agreed with the appropriate District Military Representation (RPW), attaching the BW reports, BW decision, qualification test program (PBK), as well as test methodologies and other documents required by standards and other regulations. PBK should be developed in accordance with the defense standard, as reads point 39 Annex 4 of Decision No. 72/MON of 25 March 2013 regarding the acquisition of military equipment and services for the Armed Forces of the Republic of Poland.

Moreover, the significant importance of standardization activities in the gestors' organizational system regarding military equipment is underlined by the provisions contained in Decision No. 435/MON of December 24, 2013 on determining the functions of gestors and central logistics bodies of military equipment at the Ministry of National Defense (Official Journal of the Ministry of National Defense of December 27, 2013, item 390).

The decision obliges the relevant military equipment gestor to participate in works related to standardization activities, quality assurance and codification of defense products using a codification IT system, as well as to apply for assigning a NATO warehouse number (NSN) to selected military equipment items. This task also extends to the central logistic bodies (COL), which are responsible for the participation in standardization activities and the use of standards in the planning of operations, operational/military and other tests, together with the relevant military equipment gestor.

The need to consider standardization requirements and standards is also reported in many other legal and organizational documents concerning the military technique. An example would be Decision No. 25/MON of February 7, 2014, regarding the implementation of 'Guidelines for the Review of the Needs for Operational Capabilities of the Armed Forces of the Republic of Poland' (Official Journal of the Ministry of National Defense of February 7, 2014, item 44). In this document, in point 6. General requirements for the new military equipment, standardization requirements were defined as a set of required standardization levels: compatibility, interchangeability, uniformity regarding the introduced military equipment, and a proper list of standards and standardization documents necessary to achieve interoperability was referred to. There are many more such examples and they testify to the vital role and the need to consider the provisions of standards in the areas of military technique exploitation and areas directly related to them.

N0-19-A501-1 — Physical fields of ship. Terminology, characteristic quantities is the basic standard and at the same time the first in the set of standards concerning ship's physical fields. The subject of the standard is general naming and naming of quantities characteristic for physical fields and ship surroundings, induced by the ship presence.

4 (219) 2019 
The standard specifies basic concepts of the ship's physical fields, as well as names, markings, units of measurement and designations of physical fields' characteristic quantities.

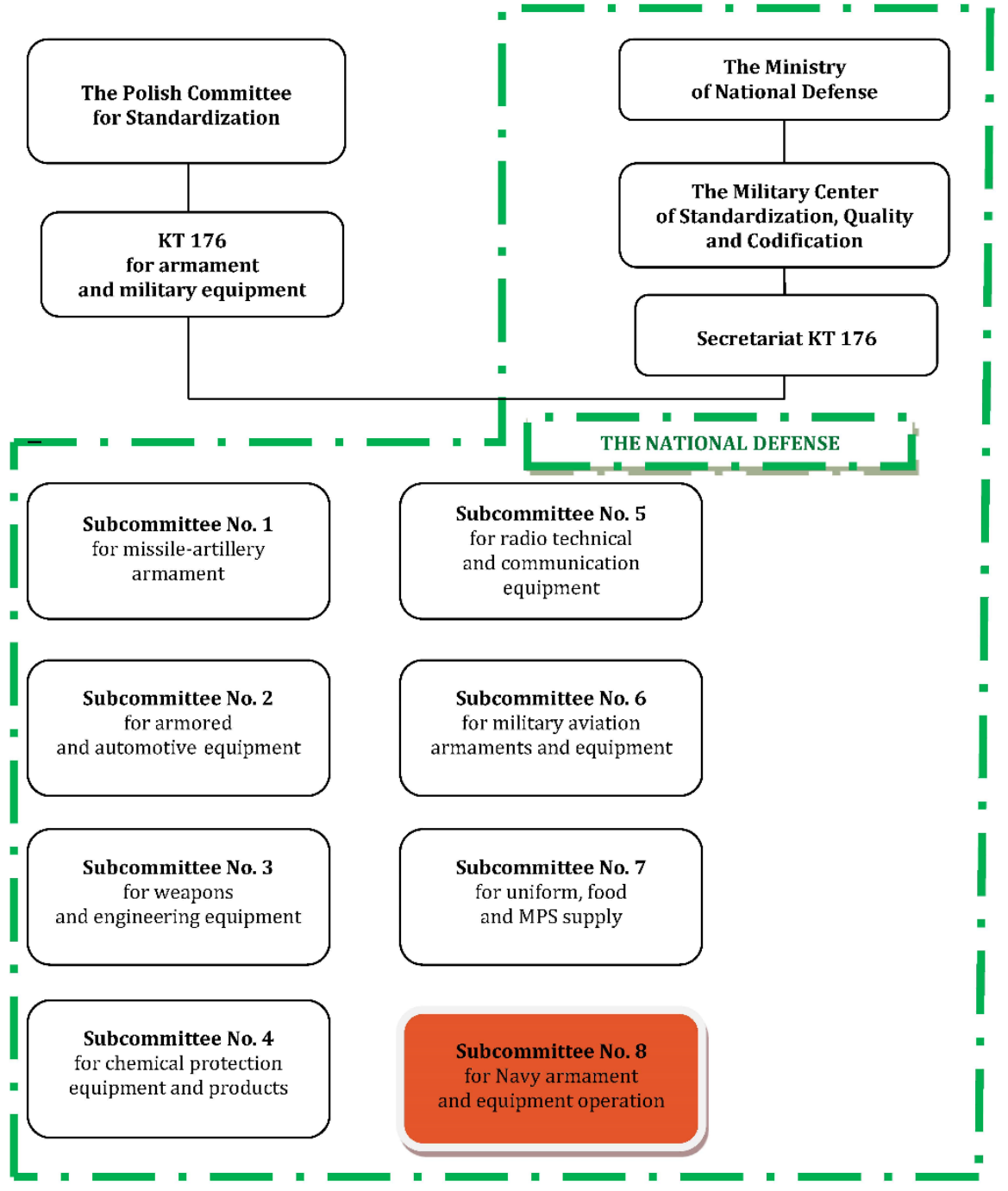

Fig. 1. Organizational and task structure of the Committee 176 for Military Technology

In the fig. 2 shown the organization of passive defense in the Polish Navy, and also the flow of information about the introduction or updating of defense standards related to the measurement of physical fields of Polish Navy ships. 


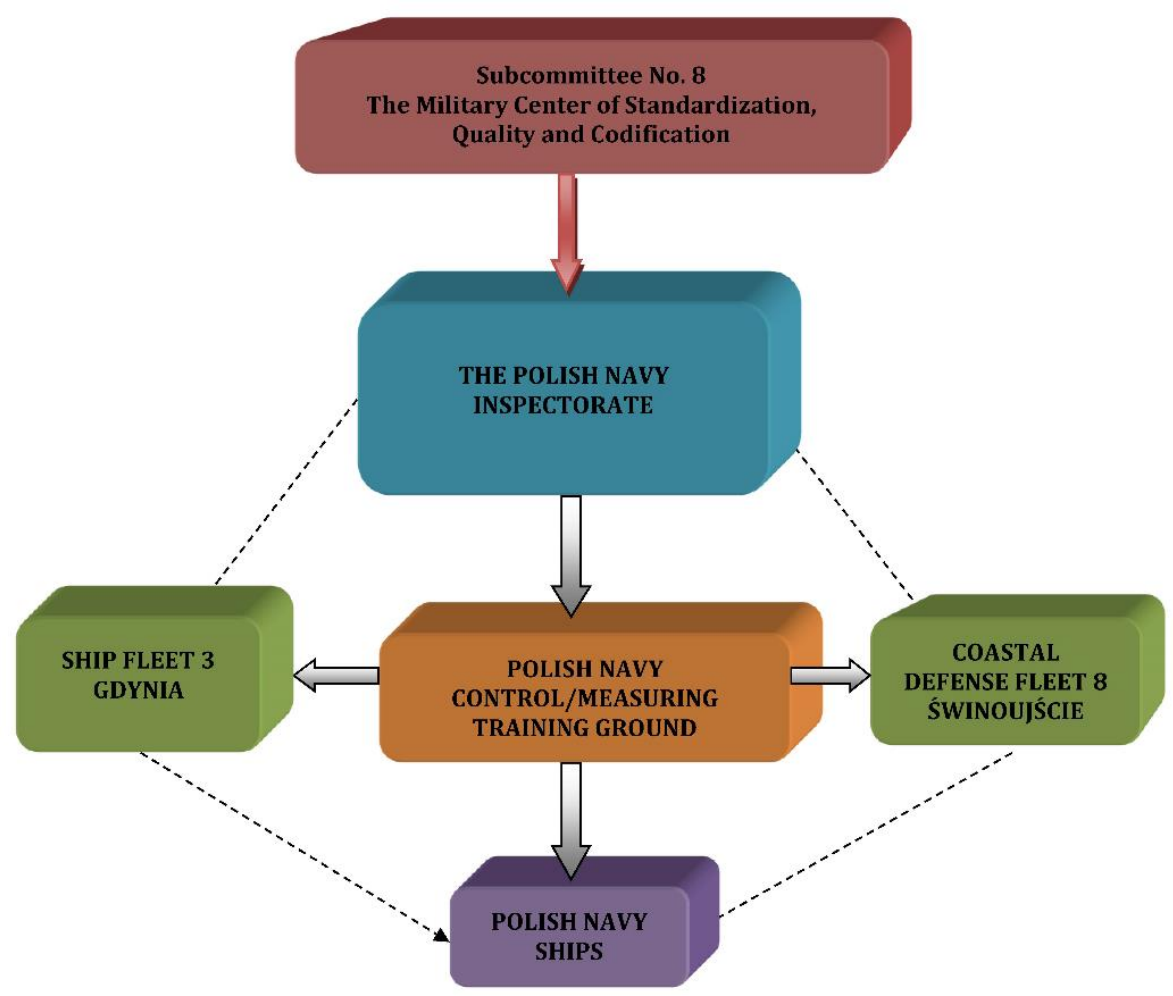

Fig. 2. The organizational chart of passive defense in the Polish Navy

The defense standards shown in tab. 1 are products of the Polish Navy's standardization activities.

Tab. 1. National ship's passive defense standardization documents

\begin{tabular}{|l|l|}
\hline \multicolumn{1}{|c|}{ Standard No. } & \multicolumn{1}{c|}{ Title } \\
\hline NO-07-A014 & $\begin{array}{l}\text { Measurement and demagnetization training grounds for ship's magnetic } \\
\text { and acoustic fields }\end{array}$ \\
\hline NO-07-A072 & Protection of ships against electromagnetic mines \\
\hline NO-07-A073 & Procedures for maritime actions. Protection of ships against acoustic mines \\
\hline NO-10-A008 & $\begin{array}{l}\text { Naval armament and equipment. Association of measurement results with } \\
\text { measurement unit standards }\end{array}$ \\
\hline NO-10-A203 & $\begin{array}{l}\text { Marine demagnetization systems. Technical requirements and evaluation } \\
\text { criteria }\end{array}$ \\
\hline NO-10-A213 & Polish Navy armament and equipment measuring systems. Requirements \\
\hline NO-19-A001 & Classification of ship's engineering and technology issues \\
\hline
\end{tabular}




\begin{tabular}{|c|c|}
\hline Standard No. & Title \\
\hline NO-19-A005 & $\begin{array}{l}\text { Protection of military-technical equipment against corrosion and aging. } \\
\text { Steel ship hulls. General requirements for electrochemical protection } \\
\text { at long-term parking }\end{array}$ \\
\hline N0-19-A008-1 & $\begin{array}{l}\text { Physical fields of ship. Allowable parameters of ship's physical fields. } \\
\text { General provisions }\end{array}$ \\
\hline NO-19-A008-2 & $\begin{array}{l}\text { Physical fields of ship. Allowable parameters of ship's physical fields. } \\
\text { Magnetic field of ship }\end{array}$ \\
\hline NO-19-A200-1 & Current flow field of ship. Terminology \\
\hline NO-19-A200-2 & Current flow field of ship. Measurement methods. General provisions \\
\hline NO-19-A200-3 & $\begin{array}{l}\text { Current flow field of ship. Electric flow field generating devices. General } \\
\text { requirements and tests }\end{array}$ \\
\hline NO-19-A200-4 & $\begin{array}{l}\text { Current flow field of ship. Sensors for measuring electrochemical potential. } \\
\text { General requirements and tests }\end{array}$ \\
\hline NO-19-A200-5 & $\begin{array}{l}\text { Current flow field of ship. Methodology for assessing electric field } \\
\text { disturbances }\end{array}$ \\
\hline NO-19-A201 & $\begin{array}{l}\text { Ship's electric field shaping systems. Technical requirements and evaluation } \\
\text { criteria }\end{array}$ \\
\hline NO-19-A203 & Ships and auxiliary vessels. Acoustic environment of ships. Requirements \\
\hline NO-19-A500 & $\begin{array}{l}\text { Electromagnetic compatibility of ship equipment. Test methods and } \\
\text { evaluation criteria }\end{array}$ \\
\hline NO-19-A501-1 & Physical fields of ship. Terminology, characteristic quantities \\
\hline NO-19-A501-2 & $\begin{array}{l}\text { Physical fields of ship. Methods for measuring control parameters of ship's } \\
\text { physical fields. General requirements }\end{array}$ \\
\hline NO-19-A501-3 & $\begin{array}{l}\text { Physical fields of ship. Methods for measuring control parameters of ship's } \\
\text { hydroacoustic field }\end{array}$ \\
\hline NO-19-A501-4 & $\begin{array}{l}\text { Physical fields of ship Methods for measuring control parameters of ship's } \\
\text { hydrodynamic field }\end{array}$ \\
\hline NO-19-A501-5 & $\begin{array}{l}\text { Physical fields of ship. Methods for measuring control parameters of ship's } \\
\text { magnetic fields }\end{array}$ \\
\hline NO-19-A501-6 & $\begin{array}{l}\text { Physical fields of ship. Methods for measuring control parameters of ship's } \\
\text { cross radar section }\end{array}$ \\
\hline NO-19-A501-7 & $\begin{array}{l}\text { Physical fields of ship. Methods for measuring control parameters of ship's } \\
\text { thermal field }\end{array}$ \\
\hline NO-19-A502 & $\begin{array}{l}\text { Navy vessels. Propulsion systems with turbine internal combustion } \\
\text { engines. Vibration measurements. Limit values }\end{array}$ \\
\hline NO-19-A503-1 & $\begin{array}{l}\text { Physical fields of ship. Ship's physical field control and measurement } \\
\text { stations. Metrological check methodologies. General provisions }\end{array}$ \\
\hline
\end{tabular}


Review of normative documents applicable in Polish Navy in the field of measurement...

\begin{tabular}{|c|c|}
\hline Standard No. & Title \\
\hline NO-19-A503-2 & $\begin{array}{l}\text { Physical fields of ship. Ship's electrical field control and measurement } \\
\text { stations. Metrological check methodologies }\end{array}$ \\
\hline NO-19-A503-3 & $\begin{array}{l}\text { Physical fields of ship. Ship's hydroacoustic field control and measurement } \\
\text { stations. Metrological check methodologies }\end{array}$ \\
\hline NO-19-A503-4 & $\begin{array}{l}\text { Physical fields of ship. Ship's hydrodynamic field control and measurement } \\
\text { stations. Metrological check methodologies }\end{array}$ \\
\hline NO-19-A503-5 & $\begin{array}{l}\text { Physical fields of ship. Ship's magnetic field control and measurement } \\
\text { stations. Metrological check methodologies }\end{array}$ \\
\hline NO-19-A503-6 & $\begin{array}{l}\text { Physical fields of ship. Ship's thermal field control and measurement } \\
\text { stations. Metrological check methodologies }\end{array}$ \\
\hline NO-19-A503-7 & $\begin{array}{l}\text { Physical fields of ship. Ship's cross radar section control and measurement } \\
\text { stations. Metrological check methodologies }\end{array}$ \\
\hline NO-19-A800 & $\begin{array}{l}\text { Protection of military-technical equipment against corrosion and aging. } \\
\text { Painting ships and their equipment. General requirements }\end{array}$ \\
\hline NO-20-A200 & $\begin{array}{l}\text { Metal-rubber ship shock absorbers. Technical requirements and evaluation } \\
\text { criteria }\end{array}$ \\
\hline NO-20-A500-2 & $\begin{array}{l}\text { Technical requirements and tests of ship's equipment and mechanisms. } \\
\text { Noise measurements and evaluation criteria }\end{array}$ \\
\hline NO-20-A500-3 & $\begin{array}{l}\text { Technical requirements and tests of ship's equipment and mechanisms. } \\
\text { Vibration measurements and evaluation criteria }\end{array}$ \\
\hline NO-20-A500-4 & $\begin{array}{l}\text { Technical requirements and tests of ship's equipment and mechanisms. } \\
\text { Vibration resistance. Test methods and evaluation criteria }\end{array}$ \\
\hline NO-20-A500-5 & $\begin{array}{l}\text { Technical requirements and tests of ship's equipment and mechanisms. } \\
\text { Total resistance to single impacts. Test methods and evaluation criteria }\end{array}$ \\
\hline NO-20-A500-6 & $\begin{array}{l}\text { Technical requirements and tests of ship's equipment and mechanisms. } \\
\text { Electromagnetic compatibility. General provisions }\end{array}$ \\
\hline NO-20-A500-7 & $\begin{array}{l}\text { Technical requirements and tests of ship's equipment and mechanisms. } \\
\text { Magnetic field. Test methods and evaluation criteria }\end{array}$ \\
\hline NO-63-A001 & $\begin{array}{l}\text { Permissible equivalent sound levels in battle stations and accommodation } \\
\text { spaces of Navy vessels. General requirements }\end{array}$ \\
\hline
\end{tabular}




\section{CONCLUSIONS}

The standardization system in place in Poland is appropriate for market economy. The standardization system does not impede technical progress, and also creates favorable conditions for free competition and contributes to scientific and technical development. This is possible only based on the provisions of the act or lower-level legal regulations, but resulting solely from the statutory delegation and this may apply to specific cases and the introduction to the use of departmental standardization documents, the fundamental of which is the defense standard.

The Regulation of the Council of Ministers of December 23, 2002, on the standardization activities related to national defense and state security also allows for incorporating provisions of foreign standardization documents, including NATO documents, into the defense standards and defense standardization textbooks, in accordance with the principles set out by the Minister of National Defense.

The Ministry of National Defense pays particular attention to the participation of industry representatives in Technical Committee No. 176 on military technology and supplies and, due to the discussed issues, in Technical Committee No. 177 for designing and production of armaments and military equipment, which is the responsibility of the Ministry of Economy. In addition, given the need to increase the competitiveness of Polish business entities cooperating in the area of defense for the Polish Armed Forces and NATO, it is possible to apply for the issue of participation recommendations by the Military Center for Standardization, Quality and Codification (together with representatives of the Ministry of National Defense) in selected NATO standardization groups in the material and technical area, as part of the Conference of National Armaments Directors - CNAD, or in groups on defense issues of the European Committee for Standardization - CEN and the European Defense Agency - EDA.

The cooperation of the Ministry of National Defense with the Polish Committee for Standardization, the Ministry of Economy, and the Ministry of the Treasury initiated by the departmental standardization service is a good predictor of the development of standardization activities for the national defense and state security, also for defense orders in the Polish Navy.

The development of technology in recent decades has caused tremendous progress in the area of building modern marine armament that responds to ship's physical fields, which has consequently forced the development of counteracting techniques [1]. Most maritime states, including NATO member states, have developed their own rules and organization to provide passive defense for their ships. Progress in this field has been conditioned by the degree of development of science, technological advancement and economic considerations of a given country. It should also 
be noted that research on the latest technologies affecting (minimizing) the size of ships' physical fields, as well as these fields' parameter values have been guarded by individual countries with appropriate security classifications.

Therefore, the Polish Navy, as part of standardization, has adopted unified principles and requirements for joint operation also in the area of measurement and minimization of ship's physical fields. Based on these new national standardization documents have been developed to supplement the already existing and newly created standards. This is forcing technological and hardware changes in the Polish Navy.

The continuous development of maritime armament has resulted in the improvement of measurement techniques, control and measurement station equipment, and training grounds as well as countermeasures on ships, which involves modernization or design and construction of better passive defense equipment of ships.

\section{REFERENCES}

[1] Bobrowicz A., Demagnetyzacja okrętów, Publ. DMW, Gdynia 1992 [Ship demagnetizing — available in Polish].

[2] Bobrowicz A., Pluszyński K., Piszczek M., Stacje kontrolno-pomiarowe pól fizycznych okrętów MW, Publ. DMW, Gdynia 1999 [Ship's physical field control and measurement stations — available in Polish].

[3] Decision No. 25/MON of February 7, 2014, regarding the implementation of 'Guidelines for the Review of the Needs for Operational Capabilities of the Armed Forces of the Republic of Poland', Official Journal of the Ministry of National Defense of February 7, 2014, item 44.

[4] Decision No. 435/MON of the Minister of National Defense of December 24, 2013, on determining the functions of gestors and central logistic bodies of military equipment at the Ministry of National Defense, Official Journal of the Ministry of National Defense of December 27, 2013, item 390.

[5] Decision No. 72/MON of March 25, 2013, regarding the acquisition of military equipment and services for the Armed Forces of the Republic of Poland, Official Journal of the Ministry of National Defense of March 25, 2013, item 78, as amended.

[6] Figurski J., Rogowski B., Stan aktualny i kierunki doskonalenia systemu normalizacji w obszarze obronności państwa, Publ. WITI, Wrocław 2014 [Current status and directions for improving the standardization system in the area of state defense - available in Polish].

[7] N0-07-A014, Measurement and demagnetization training grounds for ship's magnetic and acoustic fields.

[8] N0-07-A072, Protection of ships against electromagnetic mines.

[9] NO-10-A203, Demagnetizing systems of ship. Technical requirements and evaluation criteria.

[10] NO-19-A008-1, Physical fields of ship. Allowable parameters of ship's physical fields. General provisions.

[11] NO-19-A008-1, Physical fields of ship. Allowable parameters of ship's physical fields. Magnetic field of ship.

4 (219) 2019 
[12] NO-19-A008-1, Physical fields of ship. Methods for measuring control parameters of ship's physical fields. General requirements.

[13] NO-19-A008-1, Physical fields of ship. Methods for measuring control parameters of ship's magnetic fields.

[14] NO-19-A008-1, Physical fields of ship. Ship's magnetic field control and measurement stations. Metrological check methodologies.

[15] N0-19-A008-1, Physical fields of ship. Terminology, characteristic quantities.

[16] NO-19-A500, Electromagnetic compatibility of ship equipment. Test methods and evaluation criteria.

[17] NO-20-A500-7, Technical requirements and tests of ship's equipment and mechanisms.

\section{PRZEGLĄD DOKUMENTÓW NORMATYWNYCH OBOWIAZZUJĄCYCH W MARYNARCE WOJENNEJ RP W ZAKRESIE POMIARÓW I MINIMALIZACJI PÓL FIZYCZNYCH OKRĘTÓW}

\section{STRESZCZENIE}

W artykule przedstawiono organizację i ogólne zasady działania krajowego resortowego systemu normalizacji. Scharakteryzowano zadania realizowane w obszarze obronności i bezpieczeństwa w nowych uwarunkowaniach formalno-prawnych. Ponadto zawarto w nim krótki opis dokumentów normalizacyjnych z obszaru obronności państwa stosowanych w Siłach Zbrojnych RP oraz wskazano jeden z obszarów obejmujących normalizację zagadnień związanych z obroną bierną i pomiarami pól fizycznych w Marynarce Wojennej RP.

Normalizacja jest sposobem, za pomocą którego poprzez wprowadzanie nowego sprzętu i uzbrojenia Marynarka Wojenna RP może wspomagać rozwój potencjału wojskowego państwa, co przyczynia się również do rozwoju badań naukowych.

Słowa kluczowe:

normy obronne, normalizacja, dokumenty normatywne, pomiary pól fizycznych okrętu, obrona bierna okrętu.

$\begin{array}{ll}\text { Article history } \\ \text { Received: } & 19.09 .2019 \\ \text { Reviewed: } & 16.12 .2019 \\ \text { Revised: } & 18.12 .2019 \\ \text { Accepted: } & 19.12 .2019\end{array}$ 